MAREK GÓRKA

Politechnika Koszalińska

\title{
PROSTYTUCJA I CYBERPROSTYTUCJA JAKO ZAGROŻENIE DLA MLODYCH LUDZI - RAPORT Z BADAŃ
}

\begin{abstract}
AвSTRACt. Górka Marek, Prostytucja i cyberprostytucja jako zagrożenie dla młodych ludzi - raport z badań [Prostitution and Cyberprostitution as a Threat to Young People - a Study Report]. Studia Edukacyjne nr 46, 2017, Poznań 2017, pp. 307-323. Adam Mickiewicz University Press. ISSN 1233-6688. DOI: $10.14746 /$ SE.2017.46.20

The subject of cyberprostitution reflects the growing number of socio-political problems stemming from the dynamic development of cybertechonology and its expansion into every area of human life. In the age of cyberrevolution, there is an increase in the number of pornographic social networking sites. The sex industry quickly adopted all new information technologies to increase young people's access to pornography. As a result of the link between the internet and the sex industry, the border between the current phenomenon of prostitution and its form in cyberspace has blurred. This article, based on the study, discusses the main motivational factors that contribute to the growth of prostitution. The differences between prostitution in the real and virtual worlds are also indicated. The purpose of the study is moreover to show some disturbing phenomena that may have a negative impact - not only on the emotional development of man - but also on shaping future civil society.
\end{abstract}

Key words: cyberprofit, cyber security, security policy, education for cyber security, information society

\section{Wprowadzenie}

Dekada lat 60. i 70. XX wieku postrzegana jest jako czas wyzwolenia seksualnego. Obecną epokę, czyli drugą dekadę XXI wieku interpretuje się nie tylko jako pokłosie rewolucji internetowej, ale przede wszystkim jako ekspansję ekshibicjonizmu w cyberprzestrzeni, polegającego na masowym eksponowaniu ludzkiej intymności. Cyberprzestrzeń stanowi z całą pewnością jeden $\mathrm{z}$ istotnych problemów współczesności, któremu należy poświęcić wiele uwagi. Wynika to między innymi z tego, że obszar ten charakteryzuje się szerokim spektrum naukowym. Wiedza na temat cyberzagrożeń jest także kluczem do zrozumienia zachodzących zmian społecznych, które pozwolą 
na dokonywanie skuteczniejszych działań profilaktycznych w dziedzinie polityki bezpieczeństwa.

Technologia informatyczna z całą pewnością zrewolucjonizowała sposób, $\mathrm{w}$ jaki pornografia, a wraz $\mathrm{z}$ nią prostytucja, stała się powszechna $\mathrm{w}$ przestrzeni publicznej. Oznacza to, że liczba materiałów pornograficznych oraz dostęp do nich znacznie wzrósł. Zjawisko to obejmuje nie tylko wykroczenia związane z upowszechnianiem i wymianą nieprzyzwoitych zdjęć, ale także $z$ udostępnianiem kontrowersyjnych materiałów i amatorskich nagrań wideo.

Wraz z rozwojem technologii wzrosło również zjawisko cyberprostytucji i jak można przypuszczać, wpływ na to miało wiele czynników, jak choćby to, że Internet oferuje prawie pełną anonimowość, bez obawy, że osoba taka zostanie zidentyfikowana. Nie ma tu także stygmatyzacji społecznej, która zauważalna jest w świecie rzeczywistym. Cyberprzestrzeń oferuje również możliwość wyrażania swoich prawdziwych emocji i pragnień, bez przykrych konsekwencji i wpływu na codzienne życie.

Internet $\mathrm{w}$ kontekście wymiaru seksualnego stanowi potencjalnie niebezpieczną przestrzeń dla społeczeństwa, szczególnie jako zagrożenie dla młodych ludzi, którzy - ze względu na niedojrzałość emocjonalną, wysoki poziom zaufania oraz naiwność - mogą być predysponowani do uczestnictwa w niebezpiecznych sytuacjach. Niniejszy artykuł koncentruje się na ukazaniu roli Internetu w sferze ludzkiej intymności. Współcześnie okazuje się, że cyberprzestrzeń jest kluczowym elementem do nawiązywania kontaktów międzyludzkich. Duża część tych relacji w ramach cyberprzestrzeni polega w szczególności na zaspokajaniu wyłącznie potrzeb seksualnych.

Prostytucja znajduje się poza głównym nurtem życia społecznego. Analiza tego zjawiska może więc przyczynić się do lepszego zrozumienia procesów zachodzących w społeczeństwie. Aspekt seksualny cyberprzestrzeni stanowi intrygujący obszar badań dla wielu specjalistów z odmiennych dyscyplin naukowych. Zjawiska tego nie można zignorować, ponieważ wpływa ono na miliony osób dzisiaj i z pewnością będzie wpływać w przyszłości, tym bardziej że prostytucja jest tematem, który powraca w dyskursie publicznym.

\section{Definicja obszaru badawczego}

W pracach naukowych definicję prostytucji interpretuje się jako wymianę usług seksualnych za gotówkę i/lub inne istotne korzyści ${ }^{1}$ Proceder ten jest mocno osadzony w złożonych relacjach społecznych. Część badaczy postrzega prostytucję jako zjawisko bezpośrednio związane z męskimi popędami seksualnymi i niemożnością ich zaspokojenia w granicach małżeń-

\footnotetext{
${ }^{1}$ J. Weeks, The Languages of Sexuality, New York 2011, s. 138.
} 
stwa². Druga część artykułu dotyczy cyberprostytucji, która nie obejmuje czynności związanej z bezpośrednim kontaktem fizycznym, jednak może do niego prowadzić pod warunkiem utrzymywania dalszych relacji między użytkownikami Internetu. Cyberprostytucja jest zjawiskiem zróżnicowanym i niejednorodnym. Kiedy większość ludzi myśli o prostytucji, ma przed sobą obraz kobiet stojących na „ulicy”, jednak zjawisko to coraz bardziej zaznacza swoją obecność w codziennym życiu online. Podejście do seksualności internetowej musi więc brać pod uwagę wiele czynników. Przykładem tego są sprzeczne zachowania pewnych osób, które w świecie rzeczywistym afiszują się konserwatywnymi poglądami, natomiast $\mathrm{w}$ cyberprzestrzeni aktywnie angażują w poszukiwanie treści o charakterze pornograficznym.

Internet ułatwia również płacenie za wszelkiego rodzaju usługi seksual$n e^{3}$. Portale polegające na świadczeniu transmisji na żywo umożliwiają ich uczestnikom (po stronie odbiorców) dokonywanie opłat w zamian za angażowanie się w pokazy na żądanie. Miejsca tego typu zapewniają dostęp do obrazu z kamery, a także dają możliwość konwersacji z pozostałymi uczestnikami, jak i z osobami transmitującymi swój pokaz. Wykonawca może zostać zabrany do prywatnej sesji, w której widz płaci za określony czas i wykonywanie określonych działań. Jakkolwiek relacja ta nie dotyczy rzeczywistego, fizycznego kontaktu między dostawcą a odbiorcą, co może czynić to spotkanie akceptowalne z prawnego punktu widzenia, to jednak warunek i akceptacja płatności sprawia, że jest to forma pracy seksualnej.

Ponadto, technologia pomaga również $\mathrm{w}$ nawiązywaniu kontaktu do dalszego utrzymania relacji w świecie rzeczywistym, w którym osoby płacą za spotkania seksualne $\mathrm{z}$ inną osobą. Internauci świadczący usługi seksualne korzystają z witryn internetowych, blogów i poczty elektronicznej w celu zorganizowania spotkań z klientami. Technologia może więc służyć do realizacji pierwszego etapu, podczas którego dochodzi do rozmowy online przed spotkaniem w prawdziwym świecie ${ }^{4}$.

\section{Rozwój technologiczny}

Postawy społeczne wobec nieprzyzwoitych treści ewoluowały równocześnie z innowacją technologiczną, której produkty stały się dostępne dla konsumentów w Europie Zachodniej już w latach 70. XX wieku. W Polsce oraz

2 M.L. Skilbrei, Speaking the truth about prostitution, [w:] Prostitution Research in Context. Methodology, Representation and Power, red. M. Spanger, M.L. Skilbrei, London 2017, s. 33-46.

${ }^{3}$ J.W. Roberts, S.A. Hunt, Social control in a sexually deviant cybercommunity: A cappers' code of conduct, Deviant Behavior, 2012, 33, s. 757-773.

4 S. Cunningham, T. Kendall, Sex for Sale: Online Commerce in the World's Oldest Profession, [w:] Crime On-Line: Correlates, Causes, and Context, red. T. J. Holt, Durham 2010, s. 40-75. 
w innych krajach Europy Środkowo-Wschodniej proces ten nasilił się dopiero na przełomie lat 80. i 90., szczególnie po upadku ZSRR. Od lat 90. w polskiej przestrzeni publicznej zaczęły uwidaczniać się agencje towarzyskie oraz kluby taneczne i gabinety masażu, w których wykonywano tańce erotyczne, czy tak zwane „seks pokazy”. Z biegiem czasu bezpośrednie usługi seksualne stały się coraz bardziej tolerowane i widoczne w przestrzeni dużych miast. Obecnie billboardy czy reklamy z erotyczną treścią nie wywołują już takiej fali oburzenia społecznego. W centrach aglomeracji widoczne są hostessy rozdające ulotki i namawiające do wstąpienia do lokalu, wskazując przy tym sugestywnie na przeznaczenie tego typu miejsc.

Równocześnie, od kilku już lat usługi seksualne przekraczają próg wielu domów. Okazuje się bowiem, że pornografia bezpośrednio poprzez cybersieć i telewizję kablową trafia do wielu mieszkań. Internet zmienił dotychczasową rzeczywistość, zapewniając wiele usług, informacji i połączeń dla zainteresowanych osób. Współcześnie pornografia online stała się więc nowym wcieleniem pornografii sprzed 30 lat.

Rozwój technologii audiowizualnej, a wraz z nim pojawienie się na rynku stosunkowo niedrogich urządzeń do nagrywania w domu ułatwiło tworzenie własnych materiałów pornograficznych ${ }^{5}$. Cyfrowe kamery i aparaty fotograficzne oraz szybkie łącza internetowe umożliwiły użytkownikom upublicznianie $\mathrm{w}$ cyberprzestrzeni materiałów bezpośrednio zainteresowanym osobom $^{6}$. Popularność Sieci i technologii komputerowych doprowadziły między innymi do masowej eksplozji treści dla dorosłych, które niemal owładnęły światem Internetu.

Był to także moment przełomowy dla zjawiska tak zwanego „sponsoringu", czyli prostytucji, którą najczęściej uprawiały osoby nieletnie i przebywające na terenie popularnych galerii handlowych. W wyniku powszechnego dostępu do Internetu osoby te zaczęły świadczyć usługi seksualne w cyberprzestrzeni. Obecnie proceder ten polega głównie na płatnych transmisjach seksualnych w Internecie. Można zatem postawić hipotezę, że paradoksalnie Internet zmniejszył zjawisko realnej prostytucji wśród młodych ludzi. A zatem, nastąpił analogiczny proces do tego, jaki miał miejsce $\mathrm{w}$ dziedzinie komercjalizacji pornografii, polegający na spadku sprzedaży tradycyjnych treści seksualnych na rzecz cyberpornografii.

5 F.S. Lane, Obscene Profits: The Entrepreneurs of Pornography in the Cyber Age, New York 2000, s. 239-244.

${ }^{6}$ M. Yar, Cybercrime and Society, London 2013, s. 2-19. 


\section{Wymiar społeczno-polityczny}

Prostytucja jest tematem, który pozostaje aktualny, ponieważ pojawia się ustawicznie w sferze publicznej, a także bywa podnoszony przez część polityków w kontekście postulatu wprowadzenia jego ograniczenia bądź całkowitego zakazu. Ponadto, od momentu popularyzacji Internetu oraz jego treści, szczególnie tych o wymowie pornograficznej, pojawia się wiele pomysłów na temat ocenzurowania cyberprzestrzeni. Jednakże, niemożliwe okazuje się uregulowanie treści znajdujących się w Internecie ${ }^{7}$. Inicjatywy tego typu wywołują publiczną dyskusję na temat skomplikowanych kwestii konstytucyjnych w odniesieniu między innymi do wolności słowa. Obecnie każdy może nabyć materiały online prezentujące treści seksualne. Nadzór i kontrola, jakkolwiek skutecznie i chętnie realizowana przez wybrane instytucje publiczne, nie zdaje egzaminu przed coraz bardziej złożonym światem cyfrowym. Pornografia wykorzystuje wiele luk i możliwości, jakie tworzy prawo, polityka, kultura, czy technologia. I to Internet jest tym miejscem, nad którym trudno do końca zapanować. Niemożliwe jest także - po stronie państwa, jak i nauki - wychwycenie i zbadanie wszystkich zjawisk oraz procesów zachodzących $\mathrm{w}$ tej przestrzeni. Wiele miejsc $\mathrm{w}$ Internecie znajduje się jakby poza kontrolą reżimów i tworzy własny alternatywny świat.

Pojawiają się również propozycje, aby prostytucję (tę w realnym świecie) traktować jak każdy interes komercyjny, który miałby podlegać tym samym formom regulacji. A zatem, prostytucja miałaby stać się oficjalnie legalną „pracą seksualną", co miałoby między innymi doprowadzić do zmniejszenia stygmatyzacji osób zajmujących się tą profesją. Legalizacja zapewniłaby jednocześnie bardziej bezpieczne środowisko, w którym kobiety mogłyby pracować.

Warto jednak zauważyć, że postawy społeczne znacząco wpływają na politykę państwa i kształtowanie prawa, co widoczne jest również w stosunku do prostytucji. Wiele państw dokonało działań regulujących obecność tego procederu w przestrzeni publicznej. Przeciwnicy tego projektu zwracają jednak uwagę, że decyzja o legalizacji tego zjawiska będzie postrzegana jako akt akceptacji dla wszystkich tych, którzy chcą zaangażować się w prostytucję.

Przemysł seksualny kształtuje politykę poprzez jego obecność w sferze publicznej, co do której politycy muszą odnieść się i opowiedzieć, czy są po stronie konserwatyzmu albo po stronie liberalizmu obyczajowego. Tak więc, problem interpretacji miejsca pornografii i prostytucji może stanowić subtelny sposób na określenie granicy między konserwatywnym a liberalizmem światopoglądowym w życiu publicznym. Podobnie jak debata na temat nar-

\footnotetext{
${ }^{7}$ J.H. Lipschultz, Free expression in the age ofthe Internet, Boulder 2000, s. 23-24.
} 
kotyków, tak i dyskusje dotyczące prostytucji niewiele tłumaczą, ze względu na skomplikowany charakter tych zjawisk, często też obydwa zjawiska postrzegane są w perspektywie ocen moralnych i braku obiektywizmu.

Trudno również jednoznacznie odpowiedzieć, czy prostytucja oraz pornografia jest kwestią prywatnej moralności czy ze względu na to, że budzi społeczny niepokój, należy do problemów sfery publicznej. Takie pytania są znaczące dla polityki, ponieważ pornografia jest bardzo popularna w Internecie, a przy założeniu że cyberprzestrzeń stanowi jeden z wymiarów przestrzeni publicznej, można stwierdzić, iż pornografia jest stałym elementem otaczającej rzeczywistości. Okazuje się zatem, że z wielu powodów prostytucja jest i będzie w centrum zainteresowania środków masowego przekazu, rządów oraz opinii publicznej.

Pewien paradoks stanowi zjawisko polegające na tym, że cyberprzestrzeń - zdaniem cyberprostytutek - „oddaje przysługę" konserwatywnej części społeczeństwa oraz świata polityki, ponieważ prostytucja (oraz pornografia) $\mathrm{w}$ pewnym stopniu przeniesiona została do cyberprzestrzeni i przez to nie jest tak widoczna na co dzień sferze publicznej. Może to także przyczynić się do błędnego przekonania decydentów o stopniowym zaniku prostytucji. $\mathrm{Z}$ tego też powodu analiza tematu stanowi jeszcze większe i trudniejsze wyzwanie badawcze.

Innym ważnym przekonaniem w odniesieniu do postaw społecznych jest powszechna opinia, że korzystanie z usług seksualnych narusza tradycyjne ideały oraz kulturowe zwyczaje. Pracownicy seksualni często nie są uważani za część społeczności. Określone wspólnoty tworzą granice społeczne, które wskazują "nas" i „ich”, co może prowadzić do segregacji społecznej i wykluczenia poza nawias społeczny ${ }^{8}$. Widoczne jest to także $\mathrm{w}$ staraniach wielu władz lokalnych, aby umiejscawiać „domy publiczne” z dala od szkół, parków, kościołów, czy innych instytucji użytku publicznego.

\section{Metodologia: Cele i problemy badawcze}

Pornografia opanowała portale społecznościowe oraz inne popularne wśród młodych ludzi miejsca w cyberprzestrzeni. W 2013 roku eksperci doszli do wniosku, że co najmniej 11 procent blogów na jednym z popularnych portali społecznościowych zawiera tematykę bezpośrednio odwołującą się do pornografii ${ }^{9}$. Po kilku latach od wskazanego badania można domniemywać, że zjawisko to uległo nasileniu i w roku 2017 rozprzestrzeniło się jeszcze na

${ }^{8}$ I.M. Young, The Ideal of Community and the Politics of Difference, Philadelphia 1995, s. 158-163.

${ }^{9}$ S. Perez, Tumblr's adult fare accounts for $11.4 \%$ of site's top $200 \mathrm{k}$ domains, adult sites are leading category of referrals, http://techcrunch.com/2013/05/20/tumblrs-adult-fare-accounts-for-11- 
większą skalę. Komputery są preferowanym medium dla osób poszukujących usług w formie cyberprostytucji. Cybertechnologia pozwala im bowiem na niemal pełną anonimowość, bez strachu przed piętnowaniem społecznym lub prawnymi konsekwencjami ${ }^{10}$.

Portale społecznościowe o charakterze pornograficznym stały się niezwykle popularne $\mathrm{w}$ polskim społeczeństwie. Na podstawie obserwacji można określić, że codziennie (od poniedziałku do piątku) na jednym z tego typu portali przebywa od 35 do 40 tysięcy użytkowników. Promowanie i zachęcanie do przypadkowego seksu nie stanowi tu przeszkody dla ludzi zaangażowanych w realnym świecie w związki monogamiczne. Część portali o charakterze pornograficznym ma umieszczony na swojej witrynie tak zwany „licznik gości”, który podaje aktualną liczbę przebywających osób oraz liczbę użytkowników prowadzących transmisję. Problem wydaje się znaczący, tym bardziej że część tych portali cieszy się dużą popularnością wśród młodych ludzi. Ponadto, liczba przebywających osób na jednym z tego typu portali - późnym popołudniem i wieczorami, a szczególnie w soboty i niedziele przekracza 50 tysięcy osób. Ponieważ prostytucja jest stygmatyzowana, rzeczywista liczba osób kupująca usługi seksualne może być znacząco wyższa niż może się wydawać. Poza tym, niewiele wiadomo na temat prostytucji online, ponieważ jest ona zjawiskiem funkcjonującym mniej jawnie niż inne, oficjalne elementy życia społecznego.

Ważny problem badawczy stanowi fakt, że w dużej mierze nie dostrzega się osób zajmujących się cyberprostytucją. Wynika to z różnych względów; przede wszystkim jest to temat kontrowersyjny, trudny do analizy badawczej, a ponadto w swej naturze skryty i wymagający szczerości od osób, które są dość nieufne. Ponadto, warto zaznaczyć, że część społeczności internetowej jest bardzo hermetyczna i niechętna do udzielania informacji.

Jakkolwiek należy zaznaczyć, że postawienie znaku równości pomiędzy cyberprzestrzenią a pornografią jest błędne, to jednak powszechność dostępu do Internetu wśród młodych ludzi oraz brak kontroli rodzicielskiej, połączonej z brakiem profilaktyki w zakresie cyberbezpieczeństwa, prowadzi do zwiększonego dostępu do stron internetowych o jednoznacznym przekazie pornograficznym. Nie ma jednak sposobu na dokładną ocenę liczby młodych ludzi, którzy codziennie korzystają z Internetu i przeglądają materiały przeznaczone dla dorosłych.

Postępowanie badawcze $\mathrm{w}$ pracy polega na skonstruowaniu pytań ankietowych, zadaniem których jest scharakteryzowanie - na podstawie udzie-

4-of-sites-top-200k-domains-tumblrs-adult-fare-accounts-for-11-4-of-sites-top-200k-domainsadults-sites-are-leading-category-of-referrals [dostęp: 12.05.2017].

10 T.J. Holt, K.R. Blevins, N. Burkert, Considering the Pedophile Subculture Online, Sexual Abuse: A Journal of Research and Treatment, 2010, 22(1), s. 3-24. 
lonych odpowiedzi - dwóch odmiennych grup kobiet świadczących usługi seksualne $\mathrm{w}$ wymiarze realnym oraz w cyberprzestrzeni. Uzyskane informacje pozwalają również ukazać przyczyny występowania badanego zjawiska, jak również stanowią punkt wyjścia do oceny polityki społecznej oraz polityki bezpieczeństwa prowadzonej przez instytucje państwowe. Ze względu na specyfikę oraz miejsce przeprowadzanych badań ankietowych, osoby często narzucały narrację, determinując $w$ ten sposób zakres tematyczny dyskusji. W trakcie udzielania odpowiedzi przedstawiane przez kobiety informacje wykraczały poza ramy ankiety badawczej, co umożliwiło zweryfikowanie dotychczasowego stanu badań w dziedzinie czynników motywujących do uprawiania procederu prostytucji i cyberprostytucji.

Trudnością organizacyjną $\mathrm{w}$ przeprowadzaniu wywiadu ankietowego z dziećmi i młodzieżą (do 18. roku życia) jest wymóg uzyskania pozwolenia od rodziców oraz akceptacja psychologa, jego obecność podczas badań, jak również zgoda dyrektora szkoły. Dlatego dane wykorzystane w analizie cyberzagrożeń uzyskano od osób, które przekroczyły już 18. rok życia. Badania realizowano na podstawie bezpośrednich rozmów (z użyciem ankiet) z kobietami w przedziale wiekowym od 19 do 22 lat, które przyznawały się otwarcie do wykonywania od kilku lat usług seksualnych za wynagrodzenie. Były to również osoby zajmujące się tym procederem zarówno w świecie realnym, jak i wirtualnym. Uzyskane dane pochodzą z wywiadu przeprowadzonego z 19 kobietami świadczącymi usługi seksualne $\mathrm{w}$ tak zwanych „obiektach", które oficjalnie uznawane są za kluby „świadczące rozrywkę" lub "salony masażu” oraz z 22 kobietami, które zajmują się świadczeniem usług seksualnych w cyberprzestrzeni. Można przypuszczać, że zebrana próba badawcza jest reprezentatywna dla szerszej grupy młodych ludzi świadczących tego typu usługi.

Badane osoby dzieliły się także informacjami na temat początku wykonywanej profesji, czyli odnoszących się do sytuacji sprzed kilku lat. Innymi słowy, wszystkie kobiety z którymi przeprowadzono wywiad były pełnoletnie, jednak ich wiedza oraz przekazywane informacje oparte były na własnych doświadczeniach, jak i doświadczeniach innych osób sprzed ukończenia 18. roku życia. Dzięki temu uzyskano informacje na temat badanego zjawiska, nie łamiąc jednocześnie prawa ani nie przekraczając zasad moralnych. Wszyscy uczestnicy zostali poinformowani o celach badania oraz o możliwości wycofania się w każdej chwili. Ważne jest również, aby pamiętać o ograniczonej próbie badawczej. Badanie nie obejmuje kobiet często widocznych w przestrzeni publicznej. Zebrany materiał daje możliwość realizacji wyznaczonych celów badawczych w artykule oraz konfrontacji obydwu form prostytucji wskazanych $w$ tytule pracy. 
Zjawiska oraz procesy zachodzące w cyberrzeczywistości rodzą pytania odnośnie motywacji osób świadczących usługi seksualne. Dostępność pornografii w Internecie prowokuje także do szukania odpowiedzi na pytania o źródła tego zjawiska, a także o wpływ, jaki może wywierać nieograniczony dostęp do pornografii na młode pokolenie. Artykuł ma również na celu zbadanie wybranych zachowań młodych ludzi oraz ich doświadczeń, które rzucają światło na przemilczany często temat pornografii w Internecie.

Przeprowadzone badanie ma trzy cele: po pierwsze, zbadać zjawisko cyberprostytucji i odpowiedzieć na pytanie: czy jest ono popularnym zjawiskiem wśród młodych ludzi. Po drugie, zebrać dane mogące wskazać na różnice $w$ pojmowaniu i funkcjonowaniu prostytucji pomiędzy światem realnym i wirtualnym. Po trzecie, udowodnić potrzebę edukacji w dziedzinie cyberbezpieczeństwa.

Analiza zjawiska jest ograniczona swym zasięgiem, skupia się na wybranych osobach zajmujących się świadczeniem usług seksualnych, jednak uzyskane wypowiedzi można potraktować jako symptomy charakterystyczne dla szerszego zjawiska. Realizowanie postawionego w artykule celu dokonuje się w dużej mierze poprzez eksplorację nieznanego do końca obszaru. Niniejsze uwagi i refleksje staną się w dalszej części pracy głównym punktem odniesienia dla analizy zjawiska cyberprostytucji.

Reasumując, w artykule omówiono problem prostytucji z punktu widzenia użytkowników cyberprzestrzeni, czyli osób żyjących i pracujących w miejscach związanych z seksualnością. Podjęto próbę zbadania cyberprostytucji, przyrównując to zjawisko do jej obecności w świecie rzeczywistym. Badań dokonano, $\mathrm{w}$ formie wywiadu ankietowego, $\mathrm{z}$ osobami świadczącymi usługi seksualne w świecie realnym, jak i wirtualnym. Analizowano obszar, w którym krzyżują się postawy społeczne, zachowania internautów, elementy cyberbezpieczeństwa oraz polityka państwa w zakresie bezpieczeństwa.

Praca dotyczy postaw, wpływu i działania sfery seksualnej, która współcześnie w różnych odmianach dominuje w sferze publicznej. Jednakże, analiza zjawisk w kontekście usług seksualnych $\mathrm{w}$ artykule tym nie jest i nie może być kompleksowa, ponieważ każdego dnia Internet przynosi nowe rozwiązania z pogranicza technologii i psychologii społecznej.

\section{Wnioski z badań}

Podobnie jak w przypadku jakiejkolwiek formy pracy, istnieje wiele powodów, dla których kobiety świadczą usługi seksualne. Kwestie finansowe stanowią najczęściej przywoływane powody wśród badanych. Zdaniem 15 kobiet zaangażowanie w prostytucję jest skutecznym sposobem na zarabianie 
takiej sumy pieniędzy, której nie otrzymają one w innym miejscu pracy. Pozwala to także na kupowanie rzeczy, na które na co dzień nie mogłyby sobie pozwolić.

A zatem, jedną z przyczyn prostytucji są nierówności ekonomiczne, szczególnie widoczne w sferze tak zwanego „rynku” kobiet, w którym kupujący i sprzedawcy ustalają warunki transakcji. Prostytucja dla większości osób oferuje wystarczający dochód oraz pewien stopień autonomii i niezależności. Wszystkie przebadane kobiety (czyli 19 osób) prowadzą tak zwane podwójne życie, w celu rozwiązania problemów wynikających z sytuacji, w jakiej się znalazły.

Dla wielu młodych kobiet chęć szybkiego i łatwego zarobku jest okazją kuszącą. W zasadzie prostytucja często odpowiada na ubóstwo i trudności finansowe. $Z$ tego też między innymi powodu młodzi ludzie angażują się $\mathrm{w}$ prostytucję. Jednak droga do tego celu nie jest wcale taka prosta i oczywista; 18 badanych osób stwierdziło, że próbowały bez powodzenia poprawić swoją sytuację materialną, a świadczenie usług seksualnych było dla wielu $\mathrm{z}$ nich ostatecznością.

12 na 19 osób świadczących usługi seksualne nie miało formalnych umiejętności czy zawodu. Oprócz jednej osoby, wszystkie pozostałe kobiety nie wykazały żadnej inicjatywy w postaci poszukiwania innego źródła utrzymania, ani innego działania, na przykład uczestnictwa w szkoleniu, kursie zawodowym pozwalającym podjąć inną formę zarobku. W tym kontekście warto zauważyć, że 6 na 19 badanych kobiet dostrzegło uzależniający aspekt prostytucji, który wynika z możliwości dość szybkiego i wysokiego dochodu.

Tylko niewielka liczba osób (4 ankietowane kobiety) miały inne zatrudnienie przed podjęciem pracy seksualnej. Dla wszystkich badanych historia z prostytucją miała być sporadycznym lub nieregularnym sposobem zarabiania pieniędzy. 13 badanych kobiet zdecydowanie stwierdziło, że nienawidzi swojej pracy, jednak robi to, ponieważ potrzebuje pieniędzy. Reasumując, już na podstawie wstępnych odpowiedzi można uznać, że jedną z głównych przyczyn prostytucji w świecie rzeczywistym jest ubóstwo.

Należy jednak odnotować, że motywacja do uprawiania prostytucji jest zróżnicowana. Blisko połowa uczestniczących w ankiecie kobiet (9 osób) przyznała się również, że zdecydowała się na tę profesję ze względu na poczucie niezależności oraz niecodzienny styl życia. Badane osoby często utrzymywały intymne relacje $\mathrm{z}$ wieloma partnerami i prostytucja pojawiła się jako jedna z opcji, która - oprócz kontaktów towarzyskich - przynosi korzyści, które wcześniej nie były brane pod uwagę.

Badania ukazały również, że zjawisko prostytucji w świecie rzeczywistym ma znacznie większe tendencje kryminogenne, co w praktyce oznacza na przykład stosowanie przemocy fizycznej. Do tego typu doświadczeń przy- 
znało się 5 ankietowanych kobiet. $W$ tym kontekście warto zaznaczyć, że skala agresji wobec tej grupy społecznej może być większa, bowiem badane kobiety niechętnie wypowiadały się na ten temat. Zajmowanie się tym procederem może mieć również wpływ na zdrowie i bezpieczeństwo tych osób. Oczywiście, w zależności od miejsca i środowiska współczynnik uzależnienia od alkoholu i narkotyków jest różny. W badanej grupie żadna pytana osoba nie przyznała się do stałego zażywania narkotyków, jedynie 3 osoby potwierdziły sporadyczne zażywanie tak zwanych „miękkich narkotyków”. W opinii wszystkich badanych, picie alkoholu w niewielkich ilościach nie występuje rzadko w zakresie świadczenia usług seksualnych, ale poza tym procederem nie jest to zjawisko nagminne wśród ankietowanych.

Zdaniem wielu badaczy i obserwatorów, kobiety zaangażowane w prostytucję postrzega się jako ofiary. Mają one często za sobą trudne doświadczenia, jak również towarzyszy im szereg niekorzystnych przeżyć w dziedzinie ekonomicznej i społecznej. Często także stosowana jest wobec nich przemoc, dlatego postrzegane są one jako "podwójne ofiary"11.

$\mathrm{W}$ porównaniu z powyższymi wynikami uzyskanymi na podstawie badań ankietowych można dostrzec, że badani respondenci obecni w cyberprzestrzeni udzielili odmiennych odpowiedzi. Tak zaistniała różnica może stanowić wyjaśnienie obecności analizowanego zjawiska prostytucji w cyberprzestrzeni. Internet, zdaniem wszystkich 22 osób uczestniczących w badaniu, daje poczucie komfortu i bezpieczeństwa oraz możliwość decydowania i kontrolowania sytuacji. Zatem, można sformułować następujące pytanie: czy cyberprostytucja jest bezpieczniejszą formą prostytucji?

Kobiety pracujące $\mathrm{w}$ rzeczywistości mają mniejszy wybór i mniejszą swobodę aniżeli ich odpowiedniczki z Internetu. Osoby świadczące usługi online nie są narażone na choroby przenoszone drogą płciową. Świat wirtualny gwarantuje także kobietom kontakt z klientami w obszarze chronionym. Jedną z najczęściej powtarzających się odpowiedzi wśród badanych było poczucie bezpieczeństwa i obecność w mniej agresywnym środowisku. Należy jednak odnotować, że jakkolwiek strefa wirtualna oferuje kobietom stosunkowo bezpieczne miejsce, to jednak w 18 udzielonych odpowiedziach można odnotować opinie świadczące o trosce co do zachowania anonimowości.

W społeczeństwie istnieje wysoki stopień społecznego wstydu wokół procederu korzystania z usług prostytutki. Wynika to również ze społecznej stygmatyzacji tego środowiska, która ma swoje korzenie historyczne. W tym momencie anonimowość będąca immanentną cechą Internetu pozwala ludziom uzewnętrzniać swoje potrzeby, bez ryzyka poniesienia szkody i stygmatyzacji ze strony społeczeństwa. Ta swoista forma ekshibicjonizmu

${ }^{11}$ L. Shrage, Prostitution and the Case for Decriminalisation, Dissent, 1996, 43(2), s. 41-45. 
została wyrażona w 14 wypowiedziach. W przeciwieństwie do opinii publicznej, która piętnuje tego typu osoby, cyberświat stanowi swego rodzaju azyl przed reakcją otoczenia społecznego, a także daje uczestnikom cyberprostytucji możliwość zdefiniowania samych siebie. Żadna badana osoba nie nazwała świadczonych usług podczas transmisji publicznych mianem prostytucji, a raczej tego typu działalność określano takimi słowami, jak „,relaks”, „zabawa”, „pokaz".

Okazuje się zatem, że cyberusługi nie są tu przez uczestników stygmatyzowane, ani w żaden sposób krytykowane, do rzadkich sytuacji również - zdaniem badanych - należą przypadki agresji słownej. Wynika to być może z pewnego rodzaju etykiety, która obowiązuje uczestników oraz z możliwości usunięcia i zablokowania konta osoby, która kierowałaby się w tym miejscu mową nienawiści. Warto zatem zadać pytanie: czy tego typu działania mogą prowadzić do normalizacji i podniesienia poziomu kultury w obszarze prostytucji?

Względy ekonomiczne w przypadku cyberprostytucji, choć również ważne, nie są jednak już tak decydujące dla osób zajmujących się tym procederem. Korzyści finansowe jako priorytet w swojej działalności określiło 12 kobiet. Niewiele mniej - bowiem 10 osób - podkreśliło rolę, jaką odgrywa poczucie własnej wartości, a która zaspokajana jest poprzez otrzymywanie komplementów oraz adorację ze strony oglądających transmisję użytkowników. W uzyskanych odpowiedziach dała się także zauważyć potrzeba akceptacji ze strony otoczenia, której rzeczywistość i rówieśnicy nie zaspokajają na co dzień. A zatem, ta forma działalności może być potraktowana jako pewien substytut relacji społecznych. Innymi czynnikami, które wystąpiły w 15 badanych przypadkach i zainicjowały obecność osób świadczących usługi seksualne online były: ,ciekawość”, „rozrywka”, „relaks” i „,sposób na nudę”. Atrybuty te dla badanych osób były niemal tak ważne w hierarchii priorytetów jak poprzednie, czyli kwestie finansowe oraz dowartościowanie własnej osoby.

Spośród przebadanych osób, będących w przedziale wiekowym powyżej 18 lat, 8 przyznało się, że zaczęło świadczyć usługi seksualne online pobierając jeszcze naukę w szkole średniej. Natomiast 14 pozostałych kobiet rozpoczęło działalność w Sieci dopiero w momencie usamodzielnienia się - przebywania już poza domem. Swoją obecność na tego typu portalach tłumaczono głównie zmianą środowiska, która wiąże się z brakiem kontroli rodzicielskiej, co przyczynia się do nieskrępowanej obecności na portalach seksualnych. A zatem, wraz z odległością w wymiarze geograficznym od rodziny, wśród tych osób rośnie dystans psychologiczny od zasad czy reguł moralnych oraz pojawia się poczucie wyzwolenia.

Na marginesie warto odnotować dwie uwagi. Pierwsza dotyczy kontynuacji zjawiska cyberprostytucji, które jest realizowane w późniejszych latach 
i wynika z silnego czynnika uzależniającego te osoby. Wszystkie 8 kobiet, które rozpoczęły świadczenie usług seksualnych przed 18. rokiem życia podkreśliło ten fakt w swych wypowiedziach. Pozostała grupa także wskazywała na częstą i długotrwałą obecność na tego typu stronach internetowych. Druga uwaga dotyczy osób, które w odnotowanych 7 przypadkach boleśnie odczuwają odizolowanie od środowiska społecznego, ostracyzm oraz samotność, a obecność online daje im poczucie przynależności i akceptacji społecznej.

Co charakterystyczne, istnieje duża potrzeba budowania własnej wartości wśród osób przebywających online; wynika to być może z dystansu, jaki umożliwia Internet. W cyberprzestrzeni występują osoby, których główną motywacją jest - oprócz wspomnianych wcześniej czynników ciekawości i rozrywki - poczucie samotności, potrzeba poprawienia własnej samooceny, a także ekshibicjonizm. Ta ostatnia cecha - zdaniem 14 ankietowanych osób - nie polega na eksponowaniu własnego ciała, a raczej na opowiadaniu o swoich doświadczeniach życiowych, zmartwieniach, troskach itp. Internet jest więc dla tej grupy osób okazją i szansą na wyartykułowanie myśli, które w świecie realnym nie zostałyby wygłoszone.

Warto w miejscu tym odnotować opinię badaczy, którzy twierdzą, że następuje - wspomniana kolejny raz - normalizacja seksu na sprzedaż. Kobiety są znacznie bardziej skłonne do utrzymywania stałego kontaktu z klientami w cyberprzestrzeni, a ich relacje nabierają często pozorów romansu, randki, przyjaźni. Prostytucja zawiera wiele podobieństw do terapii czy psychoterapii $^{12}$. Badane osoby wykonujące usługi seksualne w rzeczywistości stwierdziły, że dla wielu mężczyzn seks to pretekst do wizyty, a prawdziwa potrzeba korzystania z tego typu usług wynika z czynników emocjonalnych. $Z$ definicji sprzedaż usług seksualnych jest określoną formą intymności i bliskości. Istnieją oczywiście inne zawody, które umożliwiają ujawnianie osobistych i intymnych przeżyć. Ekshibicjonizm oraz prywatne emocje eksponowane w ramach usług seksualnych stanowią część prostytucji. Uczeni odnoszą się do tego typu usług nazywając je „komercjalizacją intymności”, widząc wyraźne analogie do psychoterapeuty ${ }^{13}$. W szerszym kontekście można dostrzec także podobieństwa do innych zawodów, w których wpisany jest pewien element empatii, troski i zainteresowania klientem. Widoczne jest to choćby w pracy fryzjera czy barmana. Klienci dzielą się uczuciami i osobistymi doświadczeniami ze swojego życia. Okazuje się jednak, że zupełnie inaczej relacje układają się w cyberprzestrzeni, gdzie stroną wysłuchiwaną jest osoba sprzedająca swoje usługi seksualne.

12 E. McLeod, Working Women: Prostitution Now, London 1982, s. 28.

${ }^{13}$ J. Lever, D. Dolnick, Call Girls and Street Prostitutes: Selling Sex and Intimacy, [w:] Sex for Sale. Prostitution, Pornography and The Sex Industry, red. R. Weitzer, New York 2000, s. 188. 
Młodzi ludzie mogą być zatem zaangażowani w prostytucję w wyniku potrzeb emocjonalnych oraz na skutek złego przygotowania do samodzielnego życia. Przyczyna tkwi także w zaniedbaniu edukacji obywatelskiej, której celem jest ukształtowanie i przygotowanie osoby do dorosłego życia. Inny powód stanowi zaniżone poczucie własnej wartości. Rodzi się więc naturalna potrzeba przynależności do grupy społecznej, która oferuje poczucie akceptacji i wzajemne wsparcie.

Wszystkie badane osoby wskazały, że cyberprostytucja jest dla nich formą swobodnego wyboru, która stanowi rodzaj pragmatycznej decyzji wynikającej z najlepszej opcji, jaka była dla nich dostępna. Podobnie cała badana grupa stwierdziła również, że cyberprzestrzeń „jest na ogół bezpieczniejsza niż «ulica»". A zatem, osoby zajmujące się realną prostytucją są znacznie bardziej narażone na zagrożenia niż osoby świadczące swoje usługi online.

17 kobiet z 22-osobowej grupy badawczej odpowiedziało, że proceder ten jest dla nich ekscytujący i zapewnia im łatwy oraz bezpieczny zysk. Wspomniały, że po pewnym czasie utrzymują stały kontakt online z kilkoma użytkownikami. Klienci mogą obdarzyć ich komplementami, radami i wskazówkami życiowymi, a także dodatkowym wynagrodzeniem. Wszystkie badane osoby podkreśliły także, że mają poczucie satysfakcji z flirtowania i manipulowania z użytkownikami oglądającymi transmisje. Praca seksualna online postrzegana jest jako działalność przyjemna i nieformalna. Internet zapewnia nowy wymiar intymności, z mniejszym ryzykiem niż tradycyjne formy kontaktu. W każdej udzielonej odpowiedzi wskazano, że kontakty online zapewniają prywatność, możliwość wykonywania usług we własnym domu, bez potrzeby specjalnych przygotowań na tę okoliczność.

Analiza tych dwóch zjawisk społecznych daje możliwość porównania różnic $\mathrm{w}$ kontekście prostytucji w świecie rzeczywistym. Jednakże, przed przystąpieniem do wskazania czynników odróżniających te dwa rodzaje prostytucji należy zauważyć, że część badanych osób uczestniczy w obu tych kategoriach prostytucji. Ponad połowa przepytanych kobiet (tj. 11 osób) pracujących $\mathrm{w}$ agencjach towarzyskich przyznała, że jednocześnie wykonuje też usługi seksualne online, traktując to jako dodatkowy zarobek, który zatrzymuje dla siebie.

W kontekście omówionych wcześniej różnic w zakresie motywacji do wykonywania usług seksualnych, jak poczucie bezpieczeństwa oraz osobista satysfakcja, warto wskazać na charakterystyczne zróżnicowanie pomiędzy obydwoma grupami, które pojawiło się podczas przeprowadzanych badań. Otóż, kobiety świadczące usługi online zwykle mają rodziny i wsparcie przyjaciół, na których mogą polegać. Pewność otrzymania pomocy od najbliższych zadeklarowało 18 na 22 badane osoby. Z kolei, kobiety zajmujące się prostytucją $\mathrm{w}$ świecie realnym są znacznie bardziej osamotnione. Jedynie 6 
kobiet z 19-osobowej badanej grupy przyznało się, że może liczyć na pomoc w przypadku wystąpienia problemów. Często też nie mają one rodzin lub zostały odrzucone przez najbliższych, bądź nie utrzymują bliskich relacji rodzinnych. Nawet w kontaktach z najbliższymi nie mogą opowiedzieć o rzeczywistym źródle dochodu.

Ważny aspekt badanego zjawiska stanowi także czas zaangażowania badanych osób świadczących usługi online. Ich aktywność waha się od 6 miesięcy do 4 lat, a $\mathrm{w}$ przypadku prostytucji $\mathrm{w}$ realnym świecie zaangażowanie większości badanych osób trwa od co najmniej 5 lat. Jednakże, w realnym świecie występuje częstsza rotacja prostytutek, niż ma to miejsce w świecie wirtualnym. Jak można przypuszczać - na podstawie wywiadu - dzieje się tak z powodu przemocy fizycznej, chorób, bądź wyzysku.

Można sądzić, że wraz z upowszechnieniem cyberprzestrzeni oraz mobilnych technologii zaangażowanie w pracę seksualną dla większości użytkowników Internetu rozpocznie się przed 18. rokiem życia. Poruszając problem prostytucji, wypada podkreślić, że każdy jej wymiar skutkuje negatywnymi konsekwencjami, także jej forma elektroniczna, która jest szeroko rozpowszechnionym i dostępnym zjawiskiem w Internecie. Potwierdza to nieliczna grupa badanych kobiet, która stwierdza że również i ten rodzaj działalności może zaowocować nieprzyjemnymi doświadczeniami. Trzy badane osoby opowiadały o konsekwencjach osobistych, począwszy od zidentyfikowania tożsamości i związanej z nią późniejszej stygmatyzacji społecznej, po nawiązanie kontaktów, które mogą mieć tragiczne skutki w realnym życiu. A zatem, bez względu na miejsce, w którym odbywa się ów proceder, przemoc wobec kobiet oraz ich stygmatyzacja jest endemiczną cechą prostytucji.

\section{Zakończenie}

Kontekst kulturowy, w którym znajduje się prostytucja, ma zasadnicze znaczenie dla zrozumienia, jak jest postrzegana i jakie wzbudza emocje oraz reakcje w społeczeństwie. Jako członkowie społeczności, ludzie zdobywają specyficzną kulturowo wiedzę o kodeksach postępowania, takich jak oczekiwania i normy dobrego zachowania. Te zasady społeczne nie są uniwersalne, ponieważ odzwierciedlają konkretną kulturę, religię, zwyczaje, interakcje społeczne, a także wartości polityczne. Widoczna pornografia oraz prostytucja stanowi jedną z form mogących zakłócać porządek społeczny poprzez podważanie i kontestowanie uznanych oraz akceptowanych zasad moralnych, jak i norm prawnych.

Internet sprawił, że przeglądanie obrazów i filmów pornograficznych oraz tworzenie materiałów o identycznej bądź podobnej treści stało sie niezwykle 
łatwe dla każdej osoby posiadającej kamerę internetową w komputerze bądź telefon komórkowy. Warto zastanowić się, czy zamiarem twórców postępu technologicznego było ułatwienie ludziom komunikacji w codziennym życiu? I czy zakładali, że usprawnienia technologiczne doprowadzą do tego, że ludzie będą wysyłać zdjęcia lub filmy o prowokacyjnej i sugestywnej treści? Na koniec można postawić tezę, że obecnie jednym z głównych zastosowań cybertechnologii jest jej wykorzystywanie do produkcji i rozpowszechnianie treści seksualnych. Innowacje technologiczne i seksualność wzajemnie się uzupełniają, tworząc swego rodzaju symbiozę.

Problem cyberprostytucji nie jest zjawiskiem przejściowym; jest ono obecnie niezwykle popularne w społeczeństwie. Ponadto, cyberprostytucja - szczególnie wśród ludzi młodych - nie jest kwestią banalną i z pewnością nagłaśnianie wynikających z niej zagrożeń nie będzie przejawem nieproporcjonalnej przesady. A wręcz przeciwnie, można dostrzec, że temat ten ze względu na kontrowersyjną, wstydliwą naturę oraz na kamuflujący i poufny aspekt Internetu, a także kompromitujący element procesu wychowawczego i systemu edukacji jest marginalizowany w przestrzeni publicznej.

Społeczne podejście do prostytucji odzwierciedla wiele stereotypów i mitów, które zjawisko to otaczają. Osoby zajmujące się świadczeniem usług seksualnych postrzegane są jako zagrożenie dla wartości i interesów społecznych. Ich obraz prezentowany jest w sposób stylizowany i stereotypowy przez media, co koresponduje z zakorzenionym obrazem w świadomości społecznej. Uprzedzenia moralne są tworzone zarówno przez dziennikarzy, duchownych, polityków oraz inne osoby mające wpływ na myślenie i postrzeganie rzeczywistości przez innych ludzi ${ }^{14}$. Strach i emocje wyrosłe na gruncie stereotypów oraz masowe oburzenie i panika prowadzą do eskalacji podziałów społecznych, co nie przekłada się na lepsze zrozumienie określonej sytuacji czy zjawiska. Interpretacja oraz ocena prostytucji może wskazywać na miejsce, jakie zajmuje ona w przestrzeni społeczno-politycznej.

\section{BIBLIOGRAFIA}

Cunningham S., Kendall T., Sex for Sale: Online Commerce in the World's Oldest Profession, [w:] Crime On-Line: Correlates, Causes, and Context, red. T.J. Holt, Carolina Academic Press, Durham 2010.

Garland D., On the concept of moral panic, Crime Media Culture, 2008, 4(1).

Holt T.J., Blevins K.R., Burkert N., Considering the Pedophile Subculture Online, Sexual Abuse: A Journal of Research and Treatment, 2010, 22(1).

Lane F.S., Obscene Profits: The Entrepreneurs of Pornography in the Cyber Age, Routledge, New York 2000.

${ }^{14}$ D. Garland, On the concept of moral panic, Crime Media Culture, 2008, 4(1), s. 9-30. 
Lever J., Dolnick D., Call Girls and Street Prostitutes: Selling Sex and Intimacy, [w:] Sex for Sale. Prostitution, Pornography and The Sex Industry, red. R. Weitzer, Routledge, New York 2000.

Lipschultz J.H., Free expression in the age ofthe Internet, Westview Press, Boulder 2000.

McLeod E., Working Women: Prostitution Now, London 1982.

Perez S., Tumblr's adult fare accounts for $11.4 \%$ of site's top $200 \mathrm{k}$ domains, adult sites are leading category of referrals, za: http://techcrunch.com/2013/05/20/tumblrs-adult-fare-accounts-for-11-4-of-sites-top-200k-domains-tumblrs-adult-fare-accounts-for11-4-of-sites-top-200k-domains-adults-sites-are-leading-category-of-referrals [dostęp: 12.05.2017].

Roberts J.W., Hunt S.A., Social control in a sexually deviant cybercommunity: A cappers' code of conduct, Deviant Behavior, 2012, 33.

Shrage L., Prostitution and the Case for Decriminalisation, Dissent, 1996, 43(2).

Skilbrei M.L., Speaking the truth about prostitution, [w:] Prostitution Research in Context. Methodology, Representation and Power, red. M. Spanger, M.L. Skilbrei, Routledge, Londyn 2017.

Weeks J., The Languages of Sexuality, Routledge, New York 2011.

Yar M., Cybercrime and Society, SAGE, London 2013.

Young I.M., The Ideal of Community and the Politics of Difference, Temple University Press, Philadelphia 1995. 